\title{
Ahlat İlçesinde Yer Alan Tarihi Yığma Minarenin Yapısal Analizi
}

\author{
Ercan IŞIK ${ }^{1 *}$, Barıș ANTEP² \\ ${ }^{1}$ Bitlis Eren Üniversitesi, Mühendislik-Mimarlık Fakültesi, İnşaat Mühendisliği Bölümü, Bitlis \\ ${ }^{2}$ Bitlis Eren Üniversitesi, Fen Bilimleri Enstitüsü, Inşaat Mühendisliği Bölümü, Bitlis
}

\begin{abstract}
$\ddot{O} z$
Vangölü Havzası içerisinde yer alan Ahlat tarihi bir șehirdir. Bölgede değișik medeniyetler tarafından inșa edilmiş birçok tarihi yapı bulunmaktadır. Ahlat ilçesinde yer alan tarihi eserlerin yapısal analizlerin yapılması ile geçmiş dönemlere ait yapım teknolojileri hakkında bilgi sahibi olunabilmektedir. Bu tür eserlerin geçmiş ve gelecek arasında bir köprü görevi göreceğinden, günümüzde bu tür çalışmaların ayrı bir önemi bulunmaktadır. Bu çalışmada 1584 yılında inşa edilen Kadı Mahmut Cami’sine ait yığma tarzda inşa edilen cami minaresi dikkate alınmıştır. Minare kesme Ahlat taşından yapılmıştır. $2.75 \mathrm{mx} 2.75 \mathrm{~m}$ boyutlarında kare plan üzerine kurulan minarenin gövdesi $2 \mathrm{~m}$ çapında silindirik bir yapıya sahiptir. Minarenin toplam yüksekliği 25.10m'dir. Yerinde yapılan ölçümler sonucu elde edilen değerler yardımı ile minarenin üç boyutlu modeli yazılım programında oluşturulmuştur. Oluşturulan model sonlu elemanlar yöntemi ile analiz edilmiştir. Farklı yükleme durumlarına göre yapının deprem davranışı belirlenmeye çalışılmıştır.
\end{abstract}

Anahtar kelimeler: Ahlat, Deprem Davranışı, Minare, Yapısal, Yı̆̆ma.

\section{Structural Analysis of Historical Masonry Minaret in Ahlat}

\begin{abstract}
Ahlat is a historical town in Lake Van Basin. There are numerous historical structures in the region built by many civilizations that lived in the region. It is possible to have information about the construction techniques of the previous periods via making the structural analysis of the historical monuments in Ahlat. Due to having a function as a bridge between the past and the future, these kinds of studies have a special importance today. The minaret of Kad1 Mahmut Mosque, built in masonry style in 1528, has been taken into consideration in this study. The minaret was built from Ahlat stone. The minaret's body built on a square plan with dimensions of $2.75 \mathrm{mx} 2.75 \mathrm{~m}$ which has a cylindrical structure with a diameter of $2 \mathrm{~m}$. The total height of minaret is $25.10 \mathrm{~m}$. A three-dimensional model of the minaret was created with the help of on-site measurements. The generated model has been analysed by finite element method. It has been tried to determine earthquake behaviour of minaret according to different loading situations.
\end{abstract}

Keywords:Ahlat,Seismic Behaviour, Minaret, Structural, Masonry.

\section{Giriş}

İnsanlık tarihinin başlangıcından günümüze kadar binlerce yıllık uygarlık tarihi içinde insanın doğrudan veya doğa ile birlikte yarattığı değerler, bugün "kültürel ve doğal miras" olarak adlandırılmaktadır. Bu değerlerin korunması, çağımızda insanlığın ortak sorunudur ve üzerinde önemle durulması gereken bir konudur [1].

Kültür mirasının korunması ve geleceğe güvenle devredilmesi 21. yüzyılın önemli mühendislik araştırma ve uygulama konularının başında gelmektedir. Bu önemli konu mühendislik, mimarlık, sanat tarihi ve arkeoloji gibi bilim alanlarıyla ortak bir paydada buluştuğundan, son yıllarda oldukça önem kazanan disiplinler arası çalışma gruplarının da ilgisini çekmektedir [2].

Tarihsel mirasımızın bir sonraki nesillere aktarılabilmesi adına tarihi yapılar ile ilgili çalışmalar günümüzde önemli bir yer tutmaktadır. Özellikle minareler ile ilgili çalışmalarda bulunmaktadır [3-7].

*Sorumlu yazar:eisik@beu.edu.tr

Geliş Tarihi: 17/04/2018 Kabul Tarihi: 29/05/2018 
Ülkemizin tarihi dokusunun bozulmaması anlamında tarihi yapıların yeri çok önemlidir. Bu açıdan bu tür yapılara ait özelliklerin bilinmesi tarihi ve kültürel mirasın korunması açısından önemlidir. Tarihi ve kültürel varlıklarımızın korunması ve yaşatılması bağlamında tarihi yapıların (cami, köprü, kümbet, medrese vb.) özelliklerinin sistematik bir şekilde veri tabanına aktarılarak izlenmesi önem arz etmektedir [2].

Tarihi eserler, geçmiş ile geleceği kuvvetle bağlayan paha biçilemez kültür varlıklarımızdır. Aynı zamanda, tarihi yapılar toplumların mühendislik birikimleri, sanat anlayışları ve ekonomik durumlarının da bir göstergesidir. Van Gölü havzası tarihsel süreç içerisinde Hurri, Urartu, Med, Pers, Sasani, Selçuklu ve Osmanlı medeniyeti gibi birçok medeniyete ev sahipliği yapmıştır. Havza çok eski bir yerleşim alanı olmasından dolayı birçok uygarlığın geride bıraktığı tarihi yapı ve kültürel değerleri günümüze kadar taşımıştır. Havzada çok eski dönemlerde inşa edilen, yenileme çalışmaları yapılarak halen kullanılmakta olan birçok tarihi yapı mevcuttur. Bu havzada yer alan ve birçok medeniyete beşiklik etmiş merkezlerden biri Ahlat İlçesidir [8].

Birçok medeniyete beşiklik eden Ahlat ilçesinde türlü medeniyetlere ait çok sayıda tarihi yapı bulunmaktadır. Tarihi yapıların asırlar boyunca ayakta durması bu yapıların yapımında kullanılan malzeme özellikleri, yapım teknolojileri ile doğrudan ilgilidir. Bu bağlamda bu tür yapıların yapısal analizleri önemli bir mühendislik faaliyetidir. Tarihi yapılar ile ilgili özelliklerin arşivlenmesi ve istenildiğinde bu bilgilere kolaylıkla ulaşılabilmesi yerel yönetimler, ilgili kamu kurum ve kuruluşları ile turizm açısından önem arz etmektedir. Yerli yada yabancı turistlerin uğrak yeri olarak tarihi eser ve ören yerlerinde rehber olmadan yapılan gezintiler tarihi yapılara erişim noktasında çok fazla yarar sağlamamaktadır. Bu tür yapılara ait bilgilerin elektronik bir ortama taşınması bu bağlamda önemli bir yere sahiptir.

Yapıların depreme karşı dayanıklılığının araştırılması, yapıların deprem güvenliğinin ve güvenliğine etki eden parametrelerin belirlenmesi ve incelenmesi son yıllarda önemini arttırmıştır. $\mathrm{Bu}$ nedenlerle, yapıların deprem davranışlarının ve güvenliklerinin belirlenmesi deprem mühendisliğinin en temel çalışma alanlarından biridir. Tecrübe edilen depremlerin neticeleri göz önünde bulundurulacak olursa, yapılarda ağır hasar ve yıkımların gelişmişlik düzeyine bağlı olarak oldukça fazla olduğu gözlemlenebilir. Ancak, bu hasar ve yıkımların oluşumunda pay sahibi olan parametrelerin ayırt edilmesi ve ayrı ayrı irdelenmesi önemlidir. Bu nedenle yapıların deprem etkileri altındaki davranışları incelenirken yapıların depreme karşı dayanıklılığına etki edecek faktörlerin bilinmesi ayrı bir önem kazanmaktadır.

Çalışmada Ahlat İlçesinde bulunan önemli tarihi camilerden biri olan Kadı Mahmut Cami’sine ait cami minaresi dikkate alınmıştır. Çalışmada öncelikle minarenin yapısal özellikleri ve tarihçesinden bahsedilmiştir. Sonraki aşamada bu minarede oluşan yapısal bozulma ve hasarlara değinilerek çözüm önerileri sunulmuştur. Kadı Mahmut Cami'sine ait yığma tarzda inşa edilen minare için sonlu elemanlar yöntemi kullanılarak yapısal modelleme yapılmıştır. Oluşturulan model için farklı yükleme durumları için yazılım programında yer alan farklı eksenlerde oluşan gerilmeler hesaplanmıştır.

\section{Materyal ve Metot}

Kadı Mahmut Camii, ilçe merkezinin güneyinde bulunan Kale mahallesinde yer almaktadır. Anadolu'daki tek Osmanlı kalesinin surları içerisinde yer almaktadır (Şekil 1). Kale içinde, İskender Paşa camiinin karşısındadır. Kitabesinde yer alan bilgilere göre H.922 (M.1584) tarihinde Kadı Mahmut tarafından yapıldığı görülmektedir. Vakıflar Genel Müdürlüğünce 1982-1983 yıllarında onarım ve restorasyonu yapılan camiinin, yapılışı sade olup, Osmanlı Mimari tarzı hakimdir [9]. 2007 yılında Vakıflar Genel Müdürlüğü tarafından onarılmıştır. Bütünüyle $17.48 \mathrm{mx} 13.39 \mathrm{~m}$ ebadında bir plan üzerine inşa edilmiştir. Sadece ibadet mekanı ise $13.39 \mathrm{mx} 13.39 \mathrm{~m}$ 'lik bir kare alana sahiptir. Kuzey cephede duvarların uzantısı olan ante duvarları ile bu duvarlar arasına yerleştirilen iki sütun ile üç bölüme ayrılmış olan son cemaat yeri üç kubbeyle örtünmüştür. Anta duvarlarında bulunan pencere açıklıkları sağır nişler halinde bırakılmıştır. Doğu ve batı cephelerinde sivri kemer alınlıklı üçer penceresi bulunan caminin beden duvarları $4.34 \mathrm{~m}$ kotunda taş silmeyle nihayetlenmekte ve meyilli bir saçak pahı ile daha içeriden sekiz kenarlı kasnak başlamaktadır. 8.04m kotunda ise kasnak silmeleri yer almaktadır. Kubbe kasnağının aralarda birer kenarı boş bırakılmak suretiyle dört kenarına sivri kemerli dört pencere açılmış bulunmaktadır [9]. 
Caminin ön tarafında bir şadırvan bulunmaktadır. Günümüzde hem aktif olarak kullanması hem de yakın zamanda onarım görmesi yapının tarihi dokusunu korumuştur. Caminin taşıyıcı sistem elemanlarında herhangi bir hasara rastlanmamıștır. Yöre halkının bilinçsizce camii etrafına adak ve isimlerin yazılması tahribata yol açmıştır. Özellikle camii civarında bulunan bahçelerin sulama işlemi gerçekleştirilirken fazla suyun bırakılması sonucu camii bahçesi tahribata uğramış olup cami temeli su etkisine maruz kalmıştır. Minareyi camiyi oluşturan Ahlat taşı volkanik bir faaliyeti sonucu oluştuğundan sertlik açısından yumuşak bir malzemedir. Bunun sonucu olarak, zaman içerisinde doğal sebeplerle tahribatlar olmaktadır. Camiyi meydana getiren taşlarda oynama görünmezken minareyi meydana getiren taşlarda yer değiştirmeler söz konusudur. Ayrıca, cami yakın zamanda onarım gördüğünden çok fazla yapısal hasar oluşmamıştır.

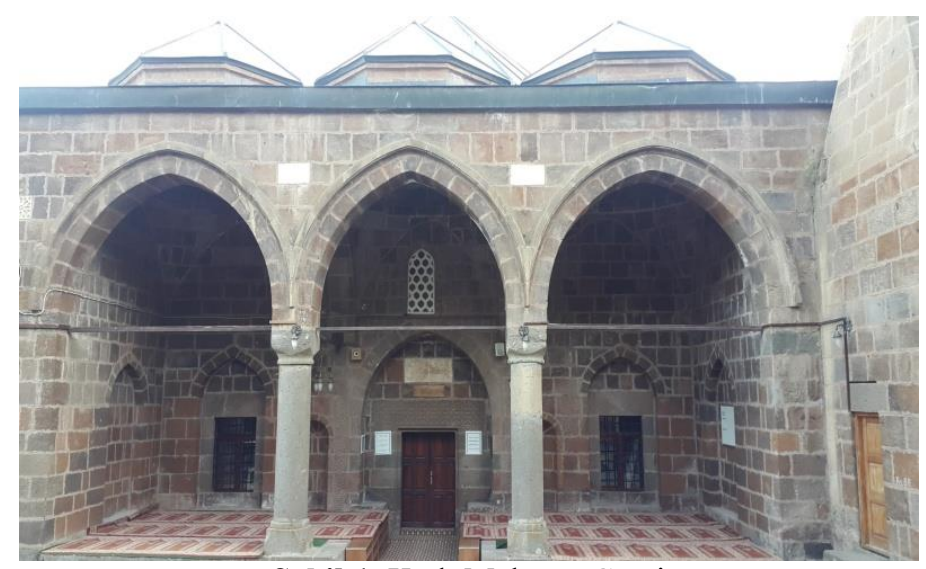

Şekil 1. Kadı Mahmut Cami

Cami ve minarenin yapımında kesme Ahlat taşı kullanılmıştır. Bitlis ili Ahlat ilçesinde önemli miktarda rezerve sahip, yöresel ismiyle Ahlat taşı olarak bilinen ignimbritler, geçmişte bölgede bulunan Nemrut kraterinin patlamasıyla oluşan volkanik lavların bölgeye yayılıp soğumasıyla meydana gelen proklastik kayaçlardır. Piroklastik bir kaya türü olan ignimbirit, hafif ve kolay işlenebilir olmasından dolayı sıklıkla tercih edilen yapıtaşlarından biridir. Çok eski zamanlardan beri özellikle Ahlat bölgesi Selçuklu mimarisinde yoğun bir şekilde kullanılan ignimbritler (Ahlattaşı), günümüzde de bölge insanı tarafindan kullanılmaya devam etmektedir [10].

Çalışmada dikkate alınan yapı Kale mahallesinin güneyinde, Osmanlı Kalesi'nde dış surları içerisinde yer alan Kadı Mahmut camisinin minaresidir. Bu minarenin boyutları 2.75x2.75m olup kare temel üzerine kurulmuştur. Gövdesi silindirik bir şekle sahip olup gövde çap1 $2 \mathrm{~m}$ 'dir. Minarenin toplam yüksekliği 25.10m'dır. Bu minareye ait görseller ve camiye ait kitabe Şekil 2'de gösterilmiştir.

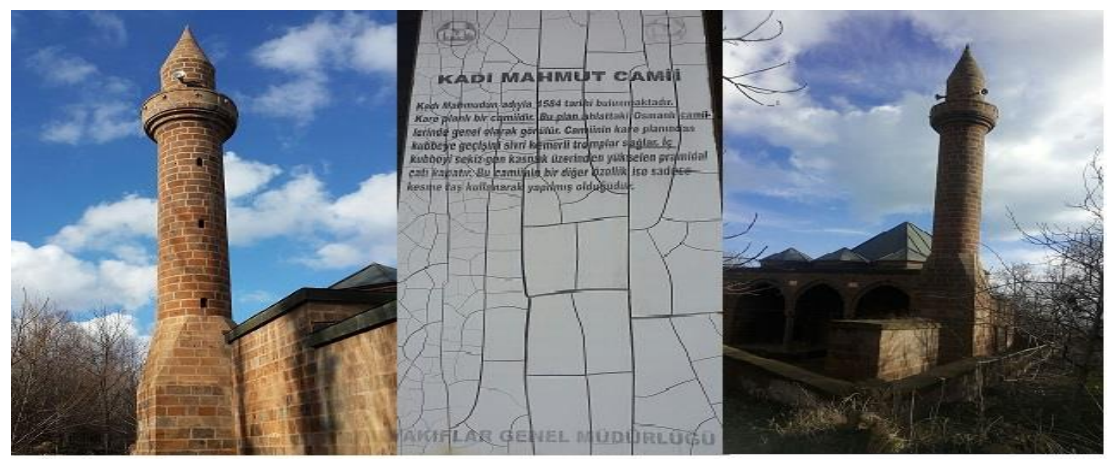

Şekil 2. Çalışmaya konu olan minare ve kitabesi

Minare, camilerde namaz zamanın geldiğini duyurmak için ezan okunan kule şeklinde inşa edilen yüksek ve ince yapılardır. Farklı malzemeler kullanılarak inşa edilme özelliklerine sahiptir. Tarihi süreçte yığma yapı olarak taş vd. malzemelerden inşa edilirken günümüzde beton, betonarme ve çelik malzemeler kullanarak da inşa edilmektedirler. Genel olarak minareler kürsü, pabuç, gövde, şerefe, petek, külah ve alemden oluşmaktadır. Kadı Mahmut Cami'sine ait minarede alem bulunmamaktadır. 
İçinde bulunan sarmal şeklindeki merdivenler kullanılarak şerefe kısmına çıkılabilmektedir. Şerefe sayıları değişiklik gösterebilmektedir. Şerefe minarenin gövde kısmından sonra gelen ezan okunan yer olarak bilinmektedir. İncelenen minareyi oluşturan kısımlar Şekil 3’te gösterilmiştir.

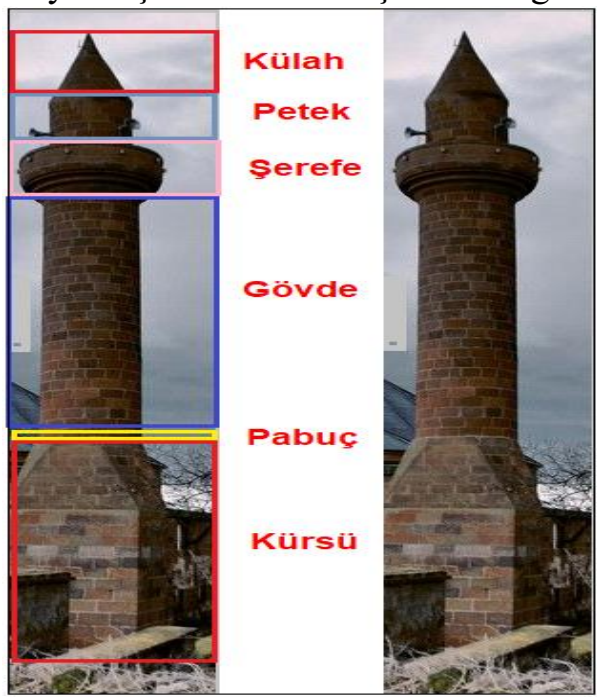

Şekil 3. İncelenen minareye ait kısımlar

Günümüzün modern mühendislik yapılarının hesap ve tasarımı için veri aktarımını kolaylaştıran, sonuçların entegre bir şekilde uygulama projelerine aktarılmasını sağlayan bir çok bilgisayar programı geliştirilmiştir. Ancak günümüze kadar varlığını sürdürmüş tarihi yapılar genellikle türbe, kümbet, camii, saray, köprü ve kale gibi kendi devirlerinin prestij yapıları olduğundan, taşıyıcı sistemlerinin şekil ve biçimleri günümüzün modern mühendislik yapılarından farklılık göstermektedir. $\mathrm{Bu}$ nedenle, tarihi yapıların yapısal çözümlemesi için en uygun hesap yöntemi sonlu elemanlar analizidir. Tarihi binaların sonlu elemanlar yöntemiyle hesabının en önemli aşaması sayısal modellemedir. Sayısal modelleme, farklı malzemelerden üretilmiş ve değişken kesit geometrisine sahip taşıyıcı sistem elemanlarının mekaniğin temel kurallarına göre doğru ve uyumlu bir şekilde matematiksel terimlere dönüştürülmesi olarak tanımlanabilir. Çalışmada öncelikle minarenin genel durumu ile ilgili yapısal analizler ile ilgili bilgiler verilecektir.

Sonlu elemanlar ile oluşturulan yapı modelleri, deneysel alternatife göre uygun maliyetli çözümler sağlayan analizler yapmaya çok elverişlidir. Ancak sonlu elemanlar yöntemlerinde malzeme için yapısal modellere ve yapının sürekliliğine bağlı olarak sonuçlar daha gerçekçi olarak elde edilmektedir Yığma yapılarda sonlu eleman ile sayısal modelleme oldukça çok hesaplamalı bir işlemi gerekmektedir [11].

Yığma yapılar için Türk Deprem Yönetmeliği (DBYBHY, 2007) [12] ve literatürde önerilen değerler dikkate alınarak seçilen tüm yapılar için malzeme değerleri elde edilmiştir. Çalışmada dikkate alınan tüm yapılarda Ahlat Taşı kullanılan tek malzeme olarak kabul edilmiştir. Ahlat taşına ait Elastisite modülü (E) ve birim hacim ağırlık $(\gamma)$ değerleri tüm yapılarda tek bir değer olarak alınmıştır. Kullanılan malzemeye ait özellikler Tablo 1'de verilmiştir. Yığma yapıların modelleme yöntemlerinden biri makro modellemedir. Bu modelleme yönteminde yığma yapıyı meydana getiren yapı elemanları ile harç arasında bir ayrım yapılmamaktadır. Yapı elemanı kompozit olarak kabul edilmektedir. Dolaysıyla yığma yapıyı meydana getiren yapı malzemesi ile harcın ortak özelliğini yansıtan eşdeğer bir malzeme modeli kullanılabilmektedir [13]. Bu çalışmada da minare modeli oluşturulurken makro modelleme kullanılmıştır. Minarede kullanılan Ahlat taşı ve bunları birbirine bağlayan harç tek bir malzeme olarak kabul edilmiştir.

Tablo 1. Malzeme özellikleri

\begin{tabular}{|c|c|c|c|c|}
\hline Malzeme cinsi & \begin{tabular}{ll}
\multicolumn{2}{c}{ Elastisite } \\
Modülü $\quad\left(\mathrm{kN} / \mathrm{m}^{2}\right)$
\end{tabular} & $\begin{array}{l}\text { Özgül Ăğırlık } \\
\qquad\left(\mathbf{k N} / \mathbf{m}^{3}\right)\end{array}$ & \begin{tabular}{l}
\multicolumn{1}{c}{ Birim } \\
Hacim Ağırlık \\
$\left(t / \mathbf{m}^{3}\right)$
\end{tabular} & Poison Oranı \\
\hline Ahlat Taşı & 5000000 & 24 & 2.45 & 0.2 \\
\hline
\end{tabular}


Hazırlanan hesap modeli üzerinde, sabit yükler ve deprem spektrumu ile tanımlanan yer hareketinin yol açtığı zorlamaların göz önüne alındığı iki ayrı yükleme durumu uygulanmıştır. Spektrum, $\mathrm{EQ}_{\mathrm{x}}$ ve $\mathrm{EQ}_{\mathrm{y}}$ yüklemesi olmak üzere ayrı ayrı iki asal doğrultuda uygulanmıştır. Spektrum için 1. derece deprem bölgesi ve Z2 dikkate alınmıştır. Sönüm oranı olarak 0.05 değeri seçilmiştir. Çalışmada dikkate alınan minarenin dinamik analizlerinde kullanılan spektrum eğrisi Şekil 4 'te gösterilmiştir.

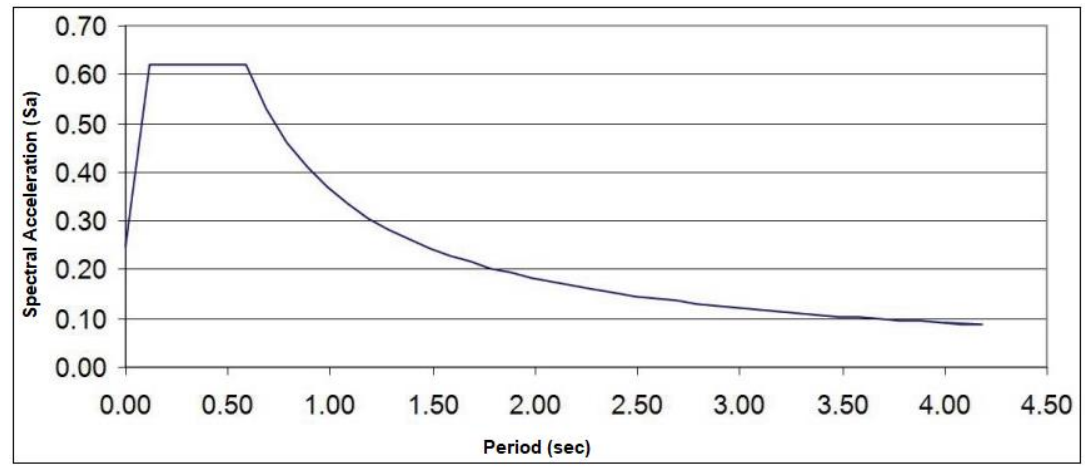

Şekil 4. Dinamik analizlerde kullanılan spektrum eğrisi

Yapının sonlu elemanlar modelinde kullanılan elemanların işaret uyumları ve yön kabulleri, sayısal modellemenin yapıldığı yazılımın [14] öngördüğ̈̈ kabullere bağlı kalınarak Şekil 5'te gösterilmiştir.
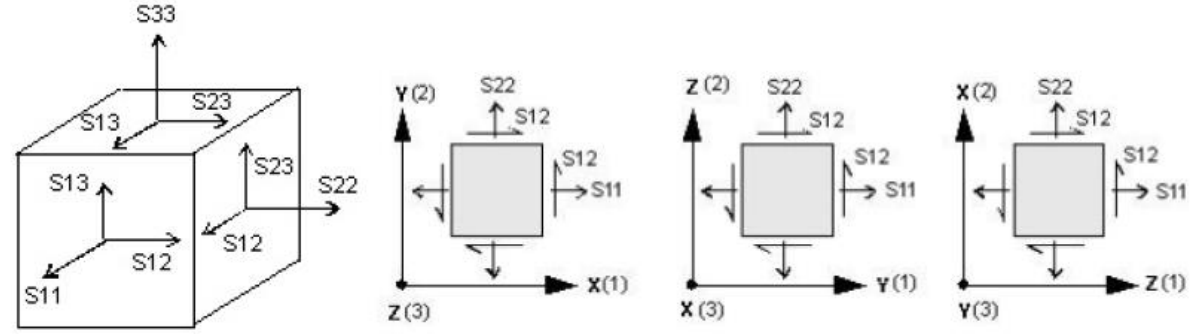

Şekil 5. İşaret uyumu ve yön kabulleri [23]

Şekil 5'da belirtildiği üzere; S11: (x) yönünde düşey gerilme, S22: (y) yönünde düşey gerilme, S33: (z) yönünde düşey gerilme, $(\mathrm{S} 12=\mathrm{S} 21)$ : $\mathrm{x}-\mathrm{y}$ düzleminde kayma gerilmeleridir.

Çalışmada incelenen minareye ait deprem analizleri SAP2000 [15] yazılım programında gerçekleştirilmiştir. Çalışmada dikkate alınan minarenin yapısal analize esas olan boyutlandırılması ve Yazılım programında elde edilen sonlu eleman modeline ait görseller Şekil 6'da gösterilmiştir.
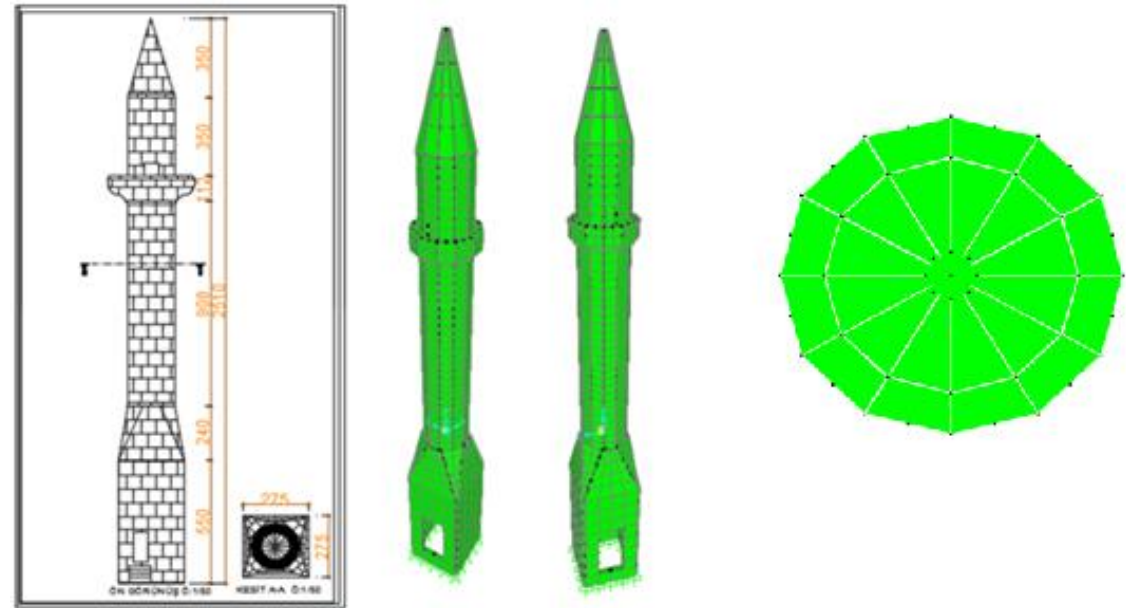

Şekil 6. İncelenen minareye ait boyutlar, yazılım programında oluşturan minare modeli ve kesiti 


\section{Bulgular ve Tartışma}

Modal analiz yapının serbest titreşim periyotlarının, frekans değerlerinin, kütle katılım oranlarının ve mod şekillerin belirlenmesini sağlayan dinamik analiz yöntemidir [13]. Minarenin dinamik özelliklerinin belirlenmesi için öncelikli olarak modal analizleri yapılmıştır. Hazırlanan sonlu eleman modeli toplam 835 adet dügüm noktası ve 769 adet SHELL eleman ile oluşturulmuştur Modal analizler yapılarak çalışmaya konu olan minarenin dinamik özellikleri belirlenmiştir. Modal analizler gerçekleştirilirken yapıda oluşan ilk 18 mod dikkate alınmıştır. Oluşturulan modelde $\mathrm{X}$ ve $\mathrm{Y}$ doğrultularına kütle katılım oranlarının \%80'in üzerinde olan modlar dikkate alınmıştır. Dolaysıyla daha fazla mod alınmasının fazla bir etkisi olmadığı görülmüştür. Modelin modal analiz sonuçlarına göre etkin modları, doğal titreşim periyotları ile kütle katılım oranları Tablo 2'de gösterilmiştir.

Tablo 2. Minare modelinin etkin kütle katılım oranları ile beraber modal analiz sonuçları

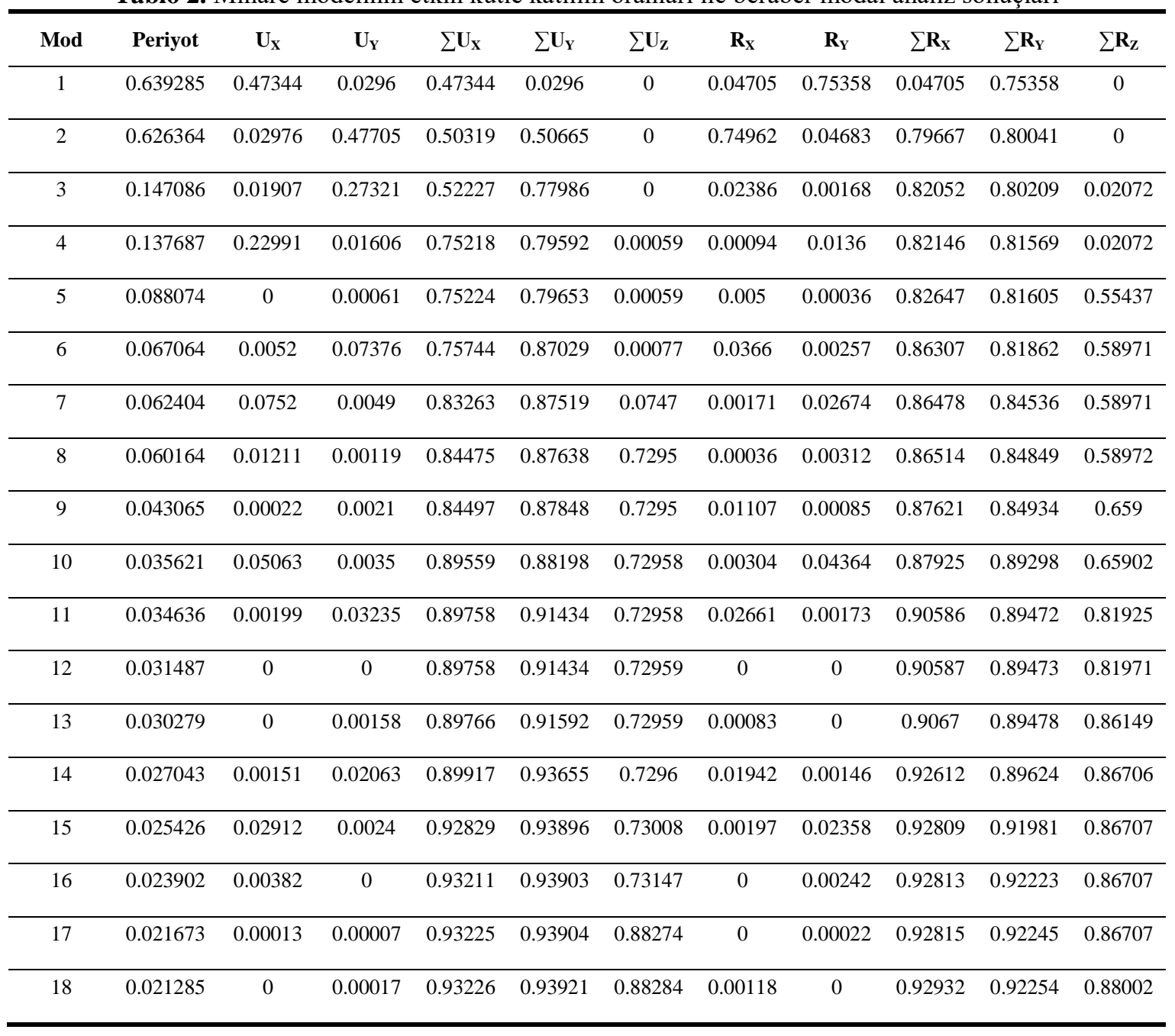

Kadı Mahmut Cami minaresinin yazılım programında analiz gerçekleştirilirken elde edilen mod şekilleri de Şekil 7'de gösterilmiştir. Burulmanın gerçekleştiği ilk 5. mod dikkate alınmıştır. 


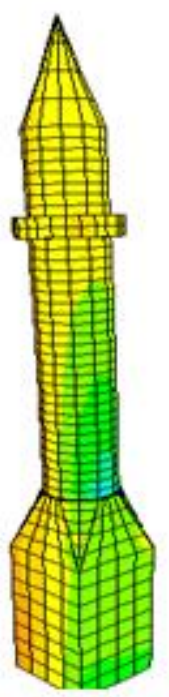

1. Mod

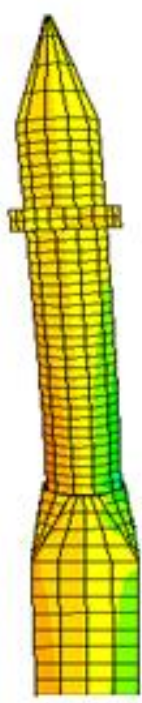

2. Mod

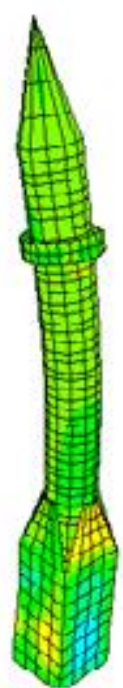

3. Mod

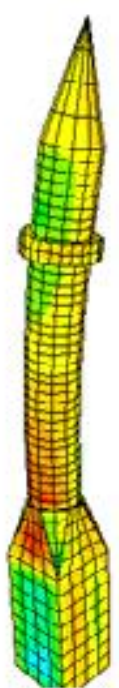

4. Mod

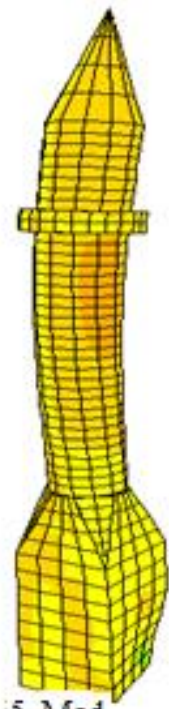

5. Mod

Şekil 7. Minare modeli için elde edilen mod şekilleri ve periyot değerleri

Gerilme hesaplamaları için sabit. hareketli ve deprem yükleri dikkate alınmıştır. Sabit yük hesaplaması malzeme özelliklerine göre yazılım programı tarafından yapılmıştır. Minare için herhangi bir hareketli yük değeri bulunmadığından bu değer sıfır olarak alınmıştır. Deprem yükleri için tanımlanan spektrumdan faydalanılmıştır. Deprem yükü için $\mathrm{EQ}_{\mathrm{x}}$ ve $\mathrm{EQ}_{\mathrm{y}}$ olmak üzerek iki doğrultuda yük tanımlaması yapılmıştır. Bu değerler kullanılarak farklı yük kombinasyonları için hesaplamalar gerçekleştirilmiştir.

Yazılım programında yer alan X doğrultusundaki düşey gerilme değerleri olan S11 için farklı yükleme durumlarına göre elde edilen gerilme diyagramları Şekil 8' de gösterilmiştir.

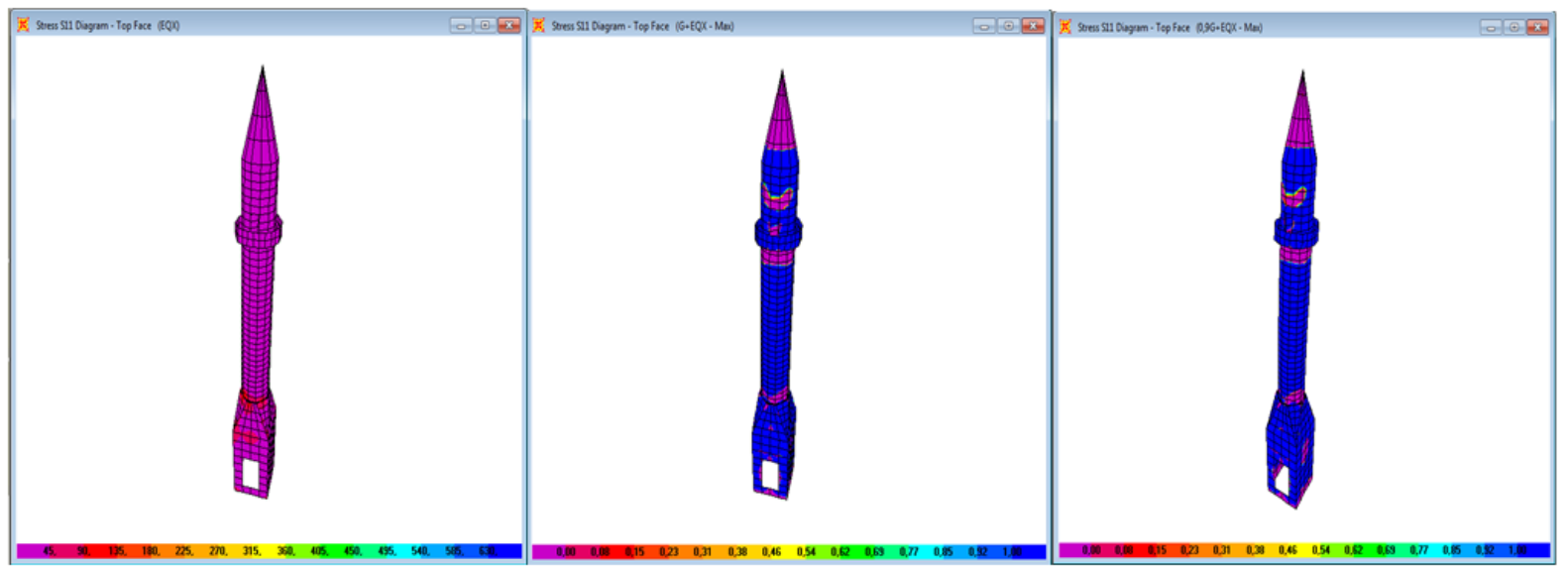

Şekil 8. Farklı yüklemelerden oluşan S11 gerilme değerleri

Yazılım programında yer alan Y doğrultusundaki düşey gerilme değerleri olan S22 için farklı yükleme durumlarına göre elde edilen gerilme diyagramları Şekil 9' da gösterilmiştir. 


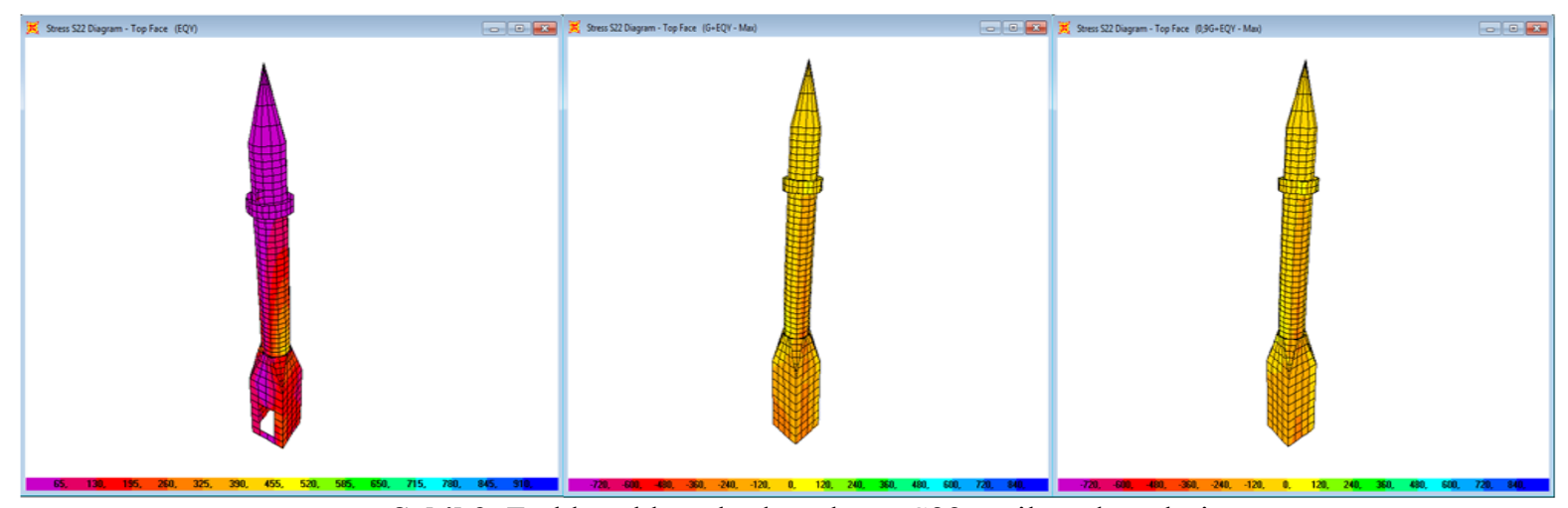

Şekil 9. Farklı yüklemelerden oluşan S22 gerilme değerleri

Yazılım programında yer alan X-Y doğrultusundaki kayma gerilme değerleri olan S12 için farklı yükleme durumlarına göre elde edilen gerilme diyagramları Şekil 10'da gösterilmiştir.

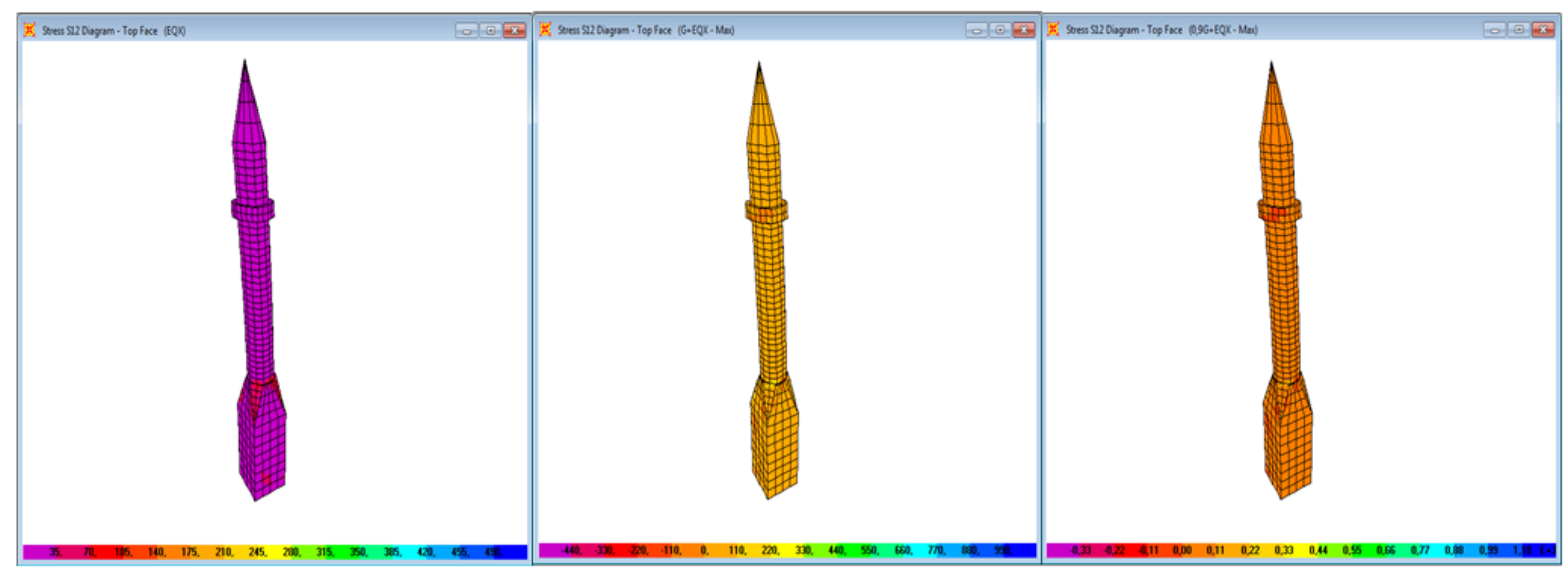

Şekil 10. Farklı yüklemelerden dolayı oluşan S12 gerilme değerleri

Analiz sonuçlarından elde edilen maksimum çekme gerilme değerleri Tablo 3 'te verilmiştir.

Tablo 3. Deprem etkisi altında görülen maksimum çekme gerilmeleri

\begin{tabular}{ccc}
\hline Yükleme türü & S11 (MPa) & S22(MPa) \\
\hline $\mathrm{G}+\mathrm{QE}_{\mathrm{X}}$ & 0.986 & 0.630 \\
& & \\
\hline $\mathrm{G}+\mathrm{QE}_{\mathrm{y}}$ & 1.216 & 0.793 \\
\hline $0.9 \mathrm{G}+\mathrm{QE}_{\mathrm{X}}$ & 0.915 & 0.584 \\
\hline $0.9 \mathrm{G}+\mathrm{QE}_{\mathrm{y}}$ & 1.146 & 0.747 \\
\hline $\mathrm{G}+\mathrm{QE}_{\mathrm{X}}+0.3 \mathrm{QE}_{\mathrm{y}}$ & 1.075 & 0.685 \\
\hline $\mathrm{G}+0.3 \mathrm{QE}_{\mathrm{X}}+\mathrm{QE}_{\mathrm{y}}$ & 1.232 & 0.799 \\
\hline
\end{tabular}

Analiz sonuçlarından elde edilen maksimum basınç gerilme değerleri Tablo 4'te verilmiştir. 
Tablo 4. Deprem etkisi altında görülen maksimum basınç gerilmeleri

\begin{tabular}{ccc}
\hline Yükleme türü & S11 (MPa) & S22(MPa) \\
\hline $\mathrm{G}+\mathrm{QE}_{\mathrm{X}}$ & 1.714 & 1.777 \\
\hline $\mathrm{G}+\mathrm{QE}_{\mathrm{y}}$ & 2.837 & 1.915 \\
\hline $0.9 \mathrm{G}+\mathrm{QE}_{\mathrm{X}}$ & 1.557 & 1.684 \\
\hline $0.9 \mathrm{G}+\mathrm{QE}_{\mathrm{y}}$ & 2.680 & 1.815 \\
\hline $\mathrm{G}+\mathrm{QE}_{\mathrm{X}}+0.3 \mathrm{QE}_{\mathrm{y}}$ & 1.937 & 1.710 \\
\hline $\mathrm{G}+0.3 \mathrm{QE}$ & & 1.847 \\
\hline
\end{tabular}

Analiz sonuçlarından elde edilen maksimum kayma gerilme değerleri Tablo 5'de verilmiştir.

Tablo 5. Deprem etkisi altında görülen maksimum kayma gerilmeleri

\begin{tabular}{cc}
\hline Yükleme türü & S12 (MPa) \\
\hline $\mathrm{G}+\mathrm{QE}_{\mathrm{X}}$ & 1.002 \\
\hline $\mathrm{G}+\mathrm{QE}_{\mathrm{y}}$ & 1.339 \\
\hline $0.9 \mathrm{G}+\mathrm{QE}_{\mathrm{X}}$ & 0.926 \\
\hline $0.9 \mathrm{G}+\mathrm{QE}_{\mathrm{y}}$ & 1.263 \\
\hline $\mathrm{G}+\mathrm{QE}_{\mathrm{X}}+0.3 \mathrm{QE}_{\mathrm{y}}$ & 1.102 \\
\hline $\mathrm{G}+0.3 \mathrm{QE}_{\mathrm{X}}+\mathrm{QE}_{\mathrm{y}}$ & 1.338 \\
\hline
\end{tabular}

Ahlat taşı için basınç dayanımı belirlenirken Şimşek ve Erdal (2004) [16] tarafından yapılan çalışmada farklı durumlardaki farklı renkteki Ahlat taşı için elde edilen basınç dayanımlarının ortalaması alınmıştır. Bu değer $11.16 \mathrm{MPa}$ olarak hesaplanmıştır. Yığma tarzda inşa edilen taş duvarlar için güvenlik kayma gerilmesi Denklem (1) ile hesaplanabilmektedir. Burada $\sigma$ malzemenin basınç dayanımını göstermektedir. Yukarıda 11.16 MPa olarak hesaplanan basınç dayanımı değeri, Denklem (1)'de yerine konarak güvenli kayma gerilmesi değeri 5.68MPa olarak hesaplanmıştır.

$\tau_{\text {em }}=0.10+0.5 \sigma \quad(\mathrm{MPa})$

Minare duvarında kullanılan Ahlat taşı. Nemrut volkanizmasının ürünü olduğundan. püskürük taşlar sınıfında değerlendirilmiştir. Püskürük taşlar için eğilmede minimum çekme dayanımı $8 \mathrm{MPa}$ olarak alınabilmektedir [17].

Analizlerden elde edilen maksimum basınç, kayma ve çekme gerilmelerinin, Ahlat taşının basınç, kayma ve çekme dayanımları olan, sırasıyla, 11.16, 5.68 ve 8 MPa değerlerinden küçük olması, bu gerilmelerin yapı tarafından güvenli bir şekilde karşılandığını göstermektedir. Bu sonuç da, yapının süreç içerisinde ayakta kalması ile uyum göstermektedir.

\section{Sonuç ve Öneriler}

Zaman içerinde doğal koşullar altında yapıyı meydana getiren taşlarda kütle kayıpları, aşınma ve kopmalar meydana gelmiştir. Ayrıca zaman içerisinde bu taşlarda liken oluşumları taşlara ayrıca zarar vermiştir. Yer yer su etkilerinden dolayı bazı kısımlarda rutubet etkileri oluşmuştur. Meydana gelen bu 
zararları düzeltebilmek ve yapının bundan sonraki süreçte fazla zarar görmemesi ve korunması ile ilgili çalışmalar yetkili kurumlar tarafindan devam etmektedir.

Bu çalışmada Ahlat ilçesinde yer alan ve yığma bir şekilde inşa edilen Kadı Mahmut Cami’sine ait minarenin deprem davranışının belirlenmesi ile ilgili bir çalışma yapılmıştır. Ayrık olarak inşa edilen minare için katı elemanlar kullanılarak sonlu eleman modeli geliştirilmiştir. Oluşturulan sonlu eleman modeli için yazılım programında yer alan S11, S22 ve S12 gerilmeleri hesaplanmıştır. Ayrıca minareye ait mod şekilleri ve periyot değerleri elde edilmiştir. Çalışmaya konu olan ve yığma tarzda inşa edilen minare hakkında bilgiler verilmiştir. Yerinde yapılan incelemeler sonucu oluşan tahribatlar ve hasarlar hakkında bilgiler verilmiştir.

Kadı Mahmut Cami'sine ait minare için kullanılan farklı yük kombinasyonları dikkate alındığında en büyük basınç gerilme değerinin 2.723MPa; en büyük kayma gerilmesi 1.339MPa ve en büyük çekme gerilmesinin $1.232 \mathrm{MPa}$ olduğu belirlenmiştir. Minarede oluşan en büyük gerilmeler minaredeki geçiş bölgeleri olarak belirlenmiştir. Elde edilen bu değerlerin yapı tarafindan karşılanabileceği sonucu ortaya çıkmaktadır. Minare için birinci mod hareketinde kaideye göre gövde ve petek elemanlarının etkisi daha büyüktür. Hasarın oluşabileceği riskli yerler minareyi meydana getiren bölümler arası birleşim elemanları olacaktır. Bu noktalarda en kesit değişmektedir. Kaide elemanın daha rijit bir yapıya sahip olması bu noktada hasarın daha az olmasına sebep olmaktadır. Dolaysıyla öncelikle hasarın bekleneceği yerler geçiş bölgeleri olacaktır.

Ahlat taşının dayanımının düşük olması ve yumuşak süngersi özelliği nedeniyle aşınma ile tahribatın fazla olması, bu durumu 1sı farklılıkları donun nemli ortamların etkilediği, parçalanmalara kopmalara yol açtığı bilinmektedir. Özellikle soğuk dönemlerde çevrimsel olarak etkili olan donmaçözülme, yöredeki yapı taşlarının bozulmasındaki en önemli etkenlerden bir tanesidir. Bu da minare için bir risk oluşturmaktadır. Dolaysıyla minarenin ana öğesi olan Ahlat taşının doğal süreçten dolayı zaman içerisinde özellik kaybı ve tahribatları yapının taşıyıcılık özelliğini etkileyebilecektir.

Minare zaman içerisinde ilgili kamu kurum ve kuruluşları tarafından izlenerek gerekli işlemlerin yapılması sonucu özgünlüğünü korumuştur. Bu işlemlerin süreklilik arz etmesi yapı için önemlidir.

Tarihi yapılar yapım sürecinde herhangi bir mühendislik hizmeti almamalarına rağmen günümüzdeki yapılara nispet yapar gibi ayakta durmaktadırlar. Zaman içerisinde oluşan hasarlara zamanında ve özgünlüğünü koruyacak şekilde yapılacak müdahaleler tarihsel mirasımızın bir sonraki nesillere aktarılması adına önemlidir. Bu eserler geçmiş ile geleceği birbirine bağlayan en önemli unsurlardır. Tarihi yapılara yapılacak müdahalelerde yapı ile ilgili tüm özelliklerin eksiksiz ve tam olarak bilinmesi yapılacak müdahalelere anlam katacaktır.

\section{Teşekkür}

Bu çalışma ikinci yazarın devam eden yüksek lisans tezinin bir bölümünden türetilmiştir.

\section{Kaynaklar}

1. Aköz F. Yüzer N. 2009. Tarihi Yapılarda Malzeme Özelliklerinin Belirlenmesinde Uygulanan Yöntemler, IMO- 1, İnsaat Muhendisliği Egitimi Sempozyumu, Turkey.

2. Iş̧1k M.F., Işık E., Bülbül M.A., Karaşin İ.B. 2017. QR Code Application for Geometric Location and Information of Historical Structures, In International Conference on Advanced Engineering Technologies (ICADET 2017), Turkey.

3. Erdil B., Tapan M., Akkaya İ., Korkut F. 2018. Effects of Structural Parameters on Seismic Behaviour of Historical Masonry Minaret, Periodica Polytechnica-Civil Engineering, 62 (1): 148161.

4. Uğurlu M.A., Günaslan S.E., Karaşin AH. 2017. Modelling and Structural Analysis of the Fourlegged Minaret, DUMF Journal of Engineering, 8 (2): 413-421.

5. Çaktı E., Saygılı Ö., Görk S., Zengin E., Oliveira C.S., Lemos J.V. 2013. Edirnekapı Mihrimah Sultan Camii Minaresinin Deprem Davranışı, Vakıf Restorasyon Yıllığı, 6: 34-40. 
6. Doğangün A., Sezen H., Tuluk Ö.İ., Livaoğlu R. Acar R. 2007. Traditional Turkish Masonry Monumental Structures and Their Earthquake Response, International Journal of Architectural Heritage, 1 (3): 251-271.

7. Muvafik M. 2014. Field Investigation and Seismic Analysis of a Historical Brick Masonry Minaret Damaged During the Van Earthquakes in 2011, Earthquakes and Structures, 6 (5): 457-472.

8. Işık E., Aydın M.C. Ülker M. 2016. Performance Evaluation of a Historical Tomb and Seismicity of the Region. Bitlis Eren University, Journal of Science and Technology, 6 (2): 59-65.

9. Kültür Portal1. 2017. https://www.kulturportali.gov.tr/turkiye/bitlis/kulturenvanteri/kadi-mahmutcam (Erişim tarihi: 15.09.2017).

10. Bakış A., Işık E., Hattatoğlu F., Akıllı A. 2014. Jeolojik Miras Nitelikli Ahlat Taşının İnşaat Sektöründe Kullanımı, III.Uluslararası Ahlat-Avrasya Bilim. Kültür ve Sanat Sempozyumu, Bitlis.

11. Giordano A., Mele E., De Luca A. 2002. Modelling of Historical Masonry Structures: Comparison of Different Approaches Through a Case Study, Engineering Structures, 24 (8): 1057-1069.

12. Turkish Earthquake Code (TEC). 2007. Turkish Earthquake Code-Specification for Structures to be Built in Disaster Areas, Turkey.

13. Mutlu Ö., Şahin A. 2016. Investigating the Effect of Modeling Approaches on Earthquake Behavior of Historical Masonry Minarets-Bursa Grand Mosque Case Study, Sigma, 7 (2): 123-136.

14. Dabanlı Ö. 2008. Tarihi Yığma Yapıların Deprem Performansının Belirlenmesi. İstanbul Teknik Üniversitesi. Yüksek Lisans Tezi, İstanbul.

15. SAP 2000 V14.0.0 Software. Structural Analysis Program.

16. Şimşek O., Erdal M. 2004. Investigation of Some Mechanical and Physical Properties of the Ahlat Stone (Ignimbrite), Gazi University Journal of Science, 17 (4): 71-78.

17. Kuruşcu A.O. 2012. Yiğma Duvar ve Temellerde Doğrusal Olmayan Modelleme. YTÜ Fen Bilimleri Enstitüsü, Doktora Tezi, İstanbul. 